\title{
A munkahelyi beilleszkedést segítő mentoring gyakorlatok és a dolgozói elkötelezettség összefüggései ${ }^{1}$
}

\author{
Kozák Anitaa - Krajcsák Zoltán \\ aEszterházy Károly Egyetem, bBudapesti Gazdasági Egyetem
}

\begin{abstract}
A TANULMÁNY CÉLJA
A tanulmány célja felvázolni, hogy a milyen összefüggések tárhatók fel a dolgozói elkötelezettség néhány dimenziója és a munkahelyi beilleszkedést segítő mentorig gyakorlatok között. A cikk a különböző (többszörös, hagyományos egyszemélyes, esetenként csoport-alapú és egyenrangú) mentoring megoldások és a folytonossági, normatív és affektív elkötelezettség közötti kapcsolatrendszert mutatja be.
\end{abstract}

\section{ALKALMAZOTT MÓDSZERTAN \\ A tanulmányban esettanulmányok segítségével szemléltetünk mentoring gyakorlatokat. Lényeges meg- jegyezni, hogy az esetek csupán érzékeltetik a mentoring gyakorlatok és az elkötelezettségi dimenziók közötti összefüggést, bizonyításukhoz későbbi kvantitatív kutatások szükségesek.}

\section{LEGFONTOSABB EREDMÉNYEK}

Eredményeink szerint a magas veszteségek alapján értelmezett folytonos elkötelezettséget a többszörös mentorálás támogatja, ebben az esetben a szervezeti integráció egyszerre segíti a dolgozó szakmai fejlödését és a vállalati kultúrával való azonosulást. Az erkölcsi meggyőződés alapú normatív elkötelezettséget a hagyományos, formális, egyszemélyes szakmai mentorálás segíti elö. Ebben az esetben a tanulás folyamata lassabb, tárgya kifejezetten szakmai, ugyanakkor a vezetői gondoskodás megnyilvánul az ismeretek és gyakorlatok alapos, átgondolt, szakaszolt átadásában, ami időben elnyúlva jobban hozzá tud járulni a szervezettel szembeni tartozás érzéséhez, az erkölcsi alapú viszonzás vágyához. Végül az esetenként csoport-alapúvá és egyenrangúvá váló mentoring gyakorlat segíti elő leginkább az affektív elkötelezettség magas fokának megjelenését, mert ebben a gyakorlatban a szociálpszichológiai támogatás gyakran felülírja a szakmai szempontok érvényesülését.

\section{GYAKORLATI JAVASLATOK}

A munkaerőhiányos környezetben különösen fontos HR és vezetői feladattá vált a dolgozói elkötelezettség növelése. A magas fluktuációs ráták miatt érdemes már a foglalkoztatás első időszakában célzottan megalapozni a munkavállalók szervezet iránti kötődését. A feldolgozott esettanulmányok felhívják a figyelmet arra, hogy az elkötelezettség egyes változói fokozhatók konkrét mentoring megoldásokkal.

Kulcsszavak: megtartásmenedzsment, folytonos elkötelezettség, affektív elkötelezettség, normatív elkötelezettség, mentori rendszer

DOI: https://doi.org/10.15170/MM.2019.53.04.05

\footnotetext{
1 A tanulmány az EFOP-3.6.1-16-2016-00001 számú, „Kutatási kapacitások és szolgáltatások komplex fejlesztése az Eszterházy Károly Egyetemen” címủ projekt keretén belül készült.
} 


\section{BEVEZETÉS}

A szervezeti vagy alkalmazotti elkötelezettségnek nemcsak definíciója, hanem az attitüdöt meghatározó dimenziók száma és a benne értelmezett tartalma tekintetében is számos megközelítése van (Angle \& Perry 1986).

Minden modern, a dolgozók munkahelyi elkötelezettségével foglalkozó modellben közös, hogy összetett, bonyolult attitủdként értelmezik, és többnyire tartalmaznak olyan változót is, amelyek bár kifejezik az egyén szervezethez való tudatos kötődését, annak magas fokát mégis kerülendőnek tartják, mert az attitüd nem mély, belső meggyőződésen alapul. Jellemzően ilyen a folytonos és a tudatos elkötelezettség. Az elkötelezettség affektív és normatív dimenziói azonban számos szervezeti változóval pozitívan korrelál, így összefüggésben áll a teljesítménnyel, a maradási szándékkal, a munkahelyi elégedettséggel, miközben erösíti a szervezeti kultúrát is.

A dolgozók munkahelyi elkötelezettsége felértékelődik akkor, ha a munkaerő utánpótlásának forrásai szükösek. Így az alacsony munkanélküliségi ráta miatt és a szakképzett pályakezdők zámának csökkenésével az új munkaerő toborzása és kiválasztása egyre nehezebbé válik. Ilyen körülmények között célszerübb lehet olyan kultúra kialakítása, ahol a bevonás, az integráció és a megtartás már belépéskor megkezdődik. Ennek egyik eszköze a mentoring lehet, amelynek különböző megoldásai eltérően befolyásolják a munkatársak elkötelezettségét is.

\section{A meggyözödés alapú munkatársi elkötelezettség}

A szervezeti elkötelezettség affektív, normatív és folytonos dimenziója (Meyer \& Allen 1991) jól ismert a munkapszichológiai kutatásokban. Az affektív elkötelezettség a szervezethez, csoporthoz, egyénekhez vagy szakmához való érzelmi alapú kötődést fejezi ki. Ahogy a motivációelméletekben, úgy a szervezeti elkötelezettségben is elkülönült dimenziót alkot, amit tovább nem tudunk bontani.

A normatív elkötelezettség olyan belső mély meggyőződésre vezethető vissza alapesetben, ami végeredményben arra készteti a dolgozót, hogy hosszú távon a szervezetben maradjon, mert a lelkiismerete szerint ez a helyes cselekedet. Későbbi kutatások szerint a normatív elkötelezettség forrása két, egymástól eltérő attitüdre is visszavezethető (Meyer \& Parfyonova 2010). Az egyik esetben a maradás erkölcsi alapú forrása az idők során a szervezetben lebonyolított tranzakciók szubjektív értéke. Minél több elismerést, dicséretet, támogatást, vagy lehetőséget kap az alkalmazott, annál erősebb lesz az erkölcsi alapú normatív elkötelezettsége. A szervezettel szembeni tartozás érzése alakul így ki az idő függvényében, aminek során az egyén vissza akar adni a vezetője vagy szervezete számára mindabból, amit addig kapott tőle. Ebben az esetben akkor sem vált munkahelyet vagy karriert, ha egyébként racionálisan az számára kifizetődő lenne. Ez az attitűd mély belső meggyőződésen alapul, szemben az eladósodottság alapú normatív elkötelezettséggel, ahol a kapott javak viszonzása csak a pillanatnyilag egyenlötlen viszony rendezéséig tart, és az elkötelezettségnek nincs más elvi mozgatórugója.

A folytonos elkötelezettség természete szintén kettős. Amennyiben egy dolgozó a munkahelyi viszonyait úgy ítéli meg, hogy az ott megszerzett javak, kiváltságok, körülmények kialkudása vagy kiérdemlése nagy áldozatokat hozott, akkor ezeket nem akarja veszni hagyni egy munkahelyváltással. Ebben az esetben a dolgozó áldozathozatal alapú folytonos elkötelezettsége magas. A folytonos elkötelezettség másik formája ezzel szemben az a szintén kalkulatív alapú meggyőződés, hogy a kevés munkaerő-piaci alternatíva miatt az egyén számára a munkahelyváltás kockázata nem éri meg. Utóbbi attitűd esetében a kényszer vagy nyomás a fő motivátor, előbbi esetében a belső meggyőződés.

A hosszú távú megtartás érdekében hasznos, ha ezek a belső meggyőződés alapú attitüdök kialakulnak, és a szervezet támogatja a magas értéküket. A munkatársak megtartásának egyik leginkább költséghatékony módja a munkavállalók e fajta elkötelezettségük tudatos növelése, szemben pl. a munkahelyi körülmények javításával, vagy a javadalmazásmenedzsment eszköztárának szélesítésével. Adott elkötelezettségi dimenzió fokozása nem jelenti azt, hogy a folyamat ne lehetne indirekt. A hazai munkavállalók elsődleges és hiteles információforrásuknak már nem a vezetőt, hanem a közvetlen kollégáikat tekintik. Ha a mentorálást és ezzel az elkötelezettségük tudatos erősítését is az ő kezükbe adjuk, akkor az ő közvetítő szerepük miatt megbízhatóbb eredményre juthatunk.

\section{A munkahelyi beilleszkedést segítö mentoring folyamat elönyei}

A hétköznapi szóhasználatban a mentorálást gyakran a coaching szinonimájaként emlegetik, a szakirodalom azonban különbséget tesz a két folyamat 
között. A coaching egy jövőorientált, általában vezetők támogatását, jobb teljesítményét szolgáló folyamat (Kelló 2018), melynek keretében egy tapasztalt külső vagy belső vállalati szakember különböző kérdezéstechnikai módszerekkel segíti rávezetni a coacholtat az eredményes munkavégzését gátló tényezők azonosítására, fejlesztési irányvonalak és célkitüzések kijelölésére (Erdélyi 2018). A mentor kifejezésnek kétféle jelentéstartalma van, egyrészt müködnek mentorok a vállalaton belüli belső támogató rendszer részeként, másrészt az új belépök szakmai integrációját is mentorok segítik. Mindkét mentor alkalmazhat coaching technikákat, de a belső támogatórendszer részeként müködő általában szintén vezetők vagy potenciális vezetök számára fenntartott mentor - már konkrét ajánláso- kat és javaslatokat is fogalmaz meg a jövőbeli munkavégzésre vonatkozóan, a beilleszkedést segítő mentor pedig az aktuális munkaköri feladatok minél magasabb szintủ állásásához és a szervezetben való eligazodáshoz nyújt támogatást.

A munkahelyi szocializáció egyik fontos pillére a mentori program, a legcélravezetőbb módja annak, hogy az új belépö megtanulja a szervezeti normákat, értékeket, attitüdöket (Wilson \& Elman 1990). A munkahelyi mentorok személye legalább annyira meghatározó a karrierfejlesztés szempontjából, mint a szervezetnél megszerzett munkatapasztalat (Miller 2002). A jól kiépített mentori program nemcsak a mentorált, de a mentor és a szervezet számára is számos előnyt jelenthet (1. táblázat).

1. táblázat: A beilleszkedést segítő mentoring folyamat előnyei

\begin{tabular}{|c|c|c|}
\hline \multicolumn{3}{|c|}{ A beilleszkedést segítő mentorig folyamat előnyei } \\
\hline \multicolumn{2}{|c|}{ Egyéni szint } & Szervezeti szint \\
\hline Mentor szempontjából & Új belépö szempontjából & \multirow[b]{2}{*}{$\begin{array}{c}\text { A mentoráltak elégedettebbek a bérük- } \\
\text { kel és a munkájukkal, produktívabbak; } \\
\text { hozzájárul az elkötelezettség kialaku- } \\
\text { lásához (ami a fluktuációs ráta csökke- } \\
\text { nését eredményezheti); tehermentesíti a } \\
\text { vezetőket; a munkahelyi közösségre és } \\
\text { a szervezeti kommunikációra is pozitív } \\
\text { hatásai lehetnek. }\end{array}$} \\
\hline $\begin{array}{l}\text { Erkölcsi és (esetleges) } \\
\text { anyagi megbecsülés; sike- } \\
\text { rélmény; karrierfejlődés; } \\
\text { a változatosabb munka- } \\
\text { feladatok és az új belépő } \\
\text { „friss” ismereteinek pozitív } \\
\text { hatásai. }\end{array}$ & $\begin{array}{l}\text { A szervezeti kultúra és a } \\
\text { szervezeten belül betöltött } \\
\text { szerepének, ellátandó } \\
\text { feladatinak könnyebb és } \\
\text { gyorsabb } \\
\text { megismerése; az esetleges } \\
\text { szorongás, belső feszültség } \\
\text { enyhülése. }\end{array}$ & \\
\hline
\end{tabular}

Forrás: saját szerkesztés

A mentorált könnyebben megismerheti a vállalati kultúrát, gyorsabban tisztázódhat számára a szervezetben betöltött szerepe és világosabb képet kaphat a karrierlehetőségeiről (Ensher et al. 2001). Emellett a mentor személye, jelenléte, szakmai útmutatásai és tanácsai megelőzhetik az új belépőben esetlegesen kialakuló szorongást, belső feszültséget. A mentor számára az effajta feladatok erkölcsi és (esetlegesen) anyagi elismeréssel járnak, emellett elégedettséget okoz és önbizalmat ad, ha az új belépő sikeresen oldja meg a szakmai problémákat (Bene 2016). A mentori feladatok később kedvezően hatnak a mentor karrierjére is (Bozionelos 2004), továbbá a változatosabb munkafeladatoknak és az új belépő „friss” ismereteinek is pozitív hozadéka lehet (Levinson 1978). Vállalati szinten azért előnyös a mentori program, mert a mentoráltak elégedettebbek a bérükkel és a munkájukkal, valamint produktívabbak (Allen et al. 2004), hozzájárul az elkötelezettség kialakulásához (Donaldson et al.
2000), ami a fluktuációs ráta csökkenését eredményezheti. Tehermentesíti a vezetőket, korábban állnak rendelkezésre teljes értékủ munkavállalók, s munkahelyi közösségre tett pozitív hatásai miatt is érdemes lehet mentort kijelölni, ugyanis segítheti a kapcsolati háló gyorsabb kiépülését, így közvetve a munkahelyi kommunikáció eredményesebb múködését.

\section{A munkahelyi beilleszkedést segitő mentor személye és a mentorálás típusai}

Vizsgálati eredményeink szerint a mentori rendszer előnyei abban az esetben érvényesülnek teljes mértékben, ha pontosan meghatározottak a program céljai, pozitív a hozzáállás a mentor, az új belépő és a menedzsment részéröl, valamint a mentori kapcsolatot szakmai bizalom és kölcsönös tisztelet 
jellemzi (Kozák - Krajcsák 2018). Ebből következően - a beszámolási kötelezettségek és a folyamatra vonatkozó egyéb formai kritériumok meghatározását követően (Szondi - Gergely 2018) a mentor kiválasztásánál a menedzsmentnek célszerü figyelembe vennie bizonyos demográfiai, tapasztalati és személyes tulajdonságokat (Allen et al. 1997). A demográfiai faktorok közé tartozik a kor, a nem és az iskolai végzettség. Tapasztalati tulajdonságok alatt a korábbi mentorként vagy mentoráltként szerzett élményeket kell érteni, amelyek befolyásolják a hajlandóságát a mentori feladatok ellátására (Ragins \& Cotton 1993). A mentor személyes tulajdonságaival kapcsolatban fontos a támogató hozzáállás, a jól informáltság, a hajlandóság a tudás/tapasztalat megosztására és a találékonyság (Cronan-Hillix et al. 1986), valamint az empátia, az elérhetőség, az öszinteség (Clark et al. 2000), a nyitottság (Niehoff 2006), a jó hallgató készség és az objektivitás (Hoffmeister 2011).

Többféle mentorálás létezik, csoportosíthatunk a folyamat formalizáltsága, célja, irányultsága és a résztvevők száma szerint (2. táblázat).

\section{2. táblázat: A mentorálás típusai}

\begin{tabular}{|c|c|c|c|}
\hline $\begin{array}{c}\text { Formalizáltság } \\
\text { szerint }\end{array}$ & \multicolumn{1}{|c|}{$\begin{array}{c}\text { A folyamat célja } \\
\text { szerint }\end{array}$} & $\begin{array}{c}\text { A folyamatban részt- } \\
\text { vevók száma szerint }\end{array}$ & $\begin{array}{c}\text { A folyamat iránya } \\
\text { szerint }\end{array}$ \\
\hline Formális, informális. & $\begin{array}{c}\text { Karrier-alapú, szociál- } \\
\text { pszichológiai. }\end{array}$ & $\begin{array}{c}\text { Egyszemélyi, többszö- } \\
\text { rös, csoport-alapú. }\end{array}$ & $\begin{array}{c}\text { Hagyományos, } \\
\text { fordított, egyanrangú. }\end{array}$ \\
\hline
\end{tabular}

Forrás: saját szerkesztés

Formális mentorálás során a mentori feladatokat és az azokat végző személyt a menedzsment jelöli ki, így a célok már a kapcsolat elején tisztázottak és részletezettek (Okurame 2012). Informális a mentorálás akkor, ha a munkavállaló dönthet a mentori feladatok elvállalásáról, kiválaszthatja a mentoráltját és a folyamat céljai a kapcsolat során alakulnak ki (Chao et al. 2006). A vizsgálati eredmények szerint a formális és az informális mentorálás elkötelezettségre és önértékelésre gyakorolt hatása között nincs különbség, viszont a formális mentorálással elégedett munkavállalók elkötelezettebbek a szervezet és a karrierjük iránt, elégedettebbek a munkájukkal, valamint magasabbra értékelik a szervezetben betöltött szerepüket, mint azok, akik kevésbé elégedettek az informális mentorukkal (Baugh \& Fagenson-Eland 2007).

A karrier-alapú mentorálás inkább a munkafolyamatok megismertetésére, a szakmai segítségnyújtásra és a karrierben való támogatásra fókuszál, a szociálpszichológiai esetében a mentor egyfajta példakép vagy szerepmodell, aki a támogató szerepét a szervezeti értékek, attitűdök átadásán és a szakmai kapcsolatok építésének segítésén keresztül látja el (Chao 2007).

Egyszemélyi mentoráláskor a folyamatban egy mentor és egy mentorált vesz részt, a többszörös esetében az új belépő számára több segítségnyújtót is kijelölnek, s az újonc az adott szituáció, szakmai kérdés függvényében dönti el, hogy melyik támogatóhoz fordul. Csoport-alapú a folyamat akkor, ha a mentornak több mentoráltja van, ilyenkor általában a szakmai segítségnyújtáson túl a csapatépítésre is fókuszálnak (Kohn \& O’Connell 2015).

Hagyományos mentoráláskor a tapasztalatátadás a mentoráltra irányul, fordított a mentorálás abban az esetben, ha - eredetileg ugyan nem így tervezték, de végül - a mentorált segít a mentornak, egyanrangú esetében pedig egymás kölcsönösen segítik a résztvevők (Grossman 2013).

Az utóbbi időben különösen, s a jövőben várhatóan még inkább felértékelődik a mentorok szerepe:

- a munkaerőhiány miatt a dolgozók munkaerö-piaci pozíciójának erősödése figyelhetö meg, ami a szervezetek közötti munkaerö-vándorlásban is tetten érhetö,

- a lineáris és a szakértői karrierutak mellett egyre gyakoribbak a spirális és átmenti jellegüek is - a spirális esetében 7-10 évente, az átmeneti karrierutaknál 2-3 évente vált szakterületet az egyén,

- a technológiai fejlődés a munkapiac alkalmazkodását, átrendeződését követeli meg: álláshelyek megszünését eredményezheti, ugyanakkor növelheti az új technológiákhoz illeszkedő kompetenciákkal rendelkező munkavállalók foglalkoztatását (Csugány 2018), 
- a munkavállalók ott fogják jól érezni magukat és teljesítenek majd átlagon felül, ahol személyiségüknek a leginkább megfelelő munkakörben, képességeiket minél teljesebben kibontakoztathatják, miközben anyagilag és erkölcsileg is elismerik munkájukat (Juhász 2019),

- $\quad$ az Y és Z generáció sajátos munkakultúrája és gyakran irreális munkapiaci-elvárásai: a kutatási eredmények tanulsága szerint amennyiben nem teljesülnek a fiatalabb korosztály munkával kapcsolatos elképzelései a szervezetnél, hajlamosak azonnal tovább állni (Gergely 2016).

Mindezek vélhetően a jelenleginél is gyakoribb munkahely- és szakmaváltást indukálnak, ami a munkahelyi szocializáció - azon belül a beilleszkedést segítő mentori programok - gördülékenyebb, munkahelyi elkötelezettséget eredményesebben megalapozó megvalósítására késztetik majd a szervezeteket.

\section{ESETTANULMÁNYOK}

Kutatásunk célja volt megtudni, hogy a különböző mentoring gyakorlatok hogyan támogatják a munkavállalói elkötelezettség dimenziónak kialakulását és erősítését. Ennek érdekében esettanulmányokat (strukturált megfigyelés, dokumentumelemzés) és félig strukturált interjús vizsgálatokat készítettünk. A kutatás 2019 első felében zajlott, a szervezeteket elérhetőségi alapon kerestük fel. Összesen öt különböző nagyvállalkozásnál jártunk, ebböl három felelt meg az elözetesen megfogalmazott kritériumainknak (formálisan is kiépített mentori rendszer, következetesség a mentorok személyének kiválasztása során, visszajelzés a folyamat eredményességéről).

Az alábbiakban tehát e három szervezetnél készített esettanulmányt mutatjuk be oly' módon, hogy azok prezentálják a munkahelyi beilleszkedést segítő mentorokok munkájának és személyiségének hatásait az új belépők szervezet iránti elkötelezettségére. Az esettanulmányokon keresztül lényesnek tartottunk rávilágítani arra is, hogy a különböző mentoring gyakorlatok a dolgozó elkötelezettség más-más dimenzióját erősítik.

\section{A többszörös mentoring hatása a magas veszteségek alapján értelmezett folytonos elkötelezettségre}

Egy banki központnál az osztályvezetők feladatés hatáskörébe tartozik a szervezeti egységüknél müködő mentori rendszer kialakítása. A bank HR részlege ugyanis csak a munkahelyi orientációt koordinálja, a mentorok személyére és a folyamat megszervezésére vonatkozóan sem írásbeli, sem szóbeli ajánlásokat nem fogalmaznak meg a vezetőknek. Az egyik adminisztrációval foglalkozó osztály vezetőjéhez jelenleg 22 diplomás munkavállaló tartozik, a szervezeti egységnél a fluktuáció a többi osztályéhoz viszonyítva átlagon felülinek tekinthető, ami - az exit interjúk tanulsága alapján - vélhetően a munka jellegéből adódó magas streszszszinttel magyarázható. Az osztályon hagyományos, formális, többszörös mentorálást alkalmaznak, az új belépő érkezését megelőzően a vezető jelöli ki a mentori feladatokat ellátó személyeket. A vezető elkötelezett a többszörös mentorálás mellett, a tapasztalatok ugyanis azt mutatják, hogy nem minden esetben sikerül jó kapcsolatot kialakítani az újoncnak a mentorával, így ha legalább két személyt jelöl ki, nagyobb az esélye a sikeres betanulási folyamatnak. A mentorokat a senior kollégák közül választja ki, ügyelve arra, hogy egyikük jó interperszonális készségekkel, a másik pedig erős szakmai háttérrel rendelkezzen. A vezető így a karrier-alapú és a szociálpszichológiai mentorálást párhuzamosan tudja biztosítani az új belépőnek, de elmondása alapján - a magas stresszint miatt inkább a szociálpszichológiai mentoráláson van a hangsúly. A szakmai anyagokat, vonatkozó belső szabályzatokat a mentorok az első héten nyomtatják ki az új belépőnek, azokat a mentorált önállóan átolvassa és a gyakorlati megvalósulásukat a mentorok munkavégzése közben figyeli meg.

Általában magától kialakul, hogy az új belépök a szakmailag erős kollégához döntően csak a munkavégzéssel kapcsolatos, míg a támogató mentorhoz minden egyéb, például szervezeti protokollt, hagyományokat és értékeket érintő kérdéssel fordulnak. Az osztályvezető elmondása alapján az is előfordult már, hogy a szociálpszichológiai támogatást nyújtó kolléga és az újonc között „,nem müködött a kémia”, ekkor a vezető a szakmai mentort négyszemközt bízta meg a szervezeti és a munkacsoportba történő integráció segítésével. A vezető a próbaidő végéig heti rendszerességgel kér visszajelzést az új dolgozótól a szakmai előre haladásáról és az általános jóllétéről, e beszélgetések alkalmával általában hagyja, hogy az újonc saját maga hozzon fel öt foglalkoztató témákat és kérdéseket. A mentorokat két-három hetente kérdezi meg az új munkatársról, de a kialakult gyakorlat szerint azok általában maguktól jelentkeznek és számolnak be az elöre haladásról.

Ez a gyakorlat egyszerre formálja tehát a mentorált szakmai készségeit a szakmai mentor 
munkája által, és segíti elő az interperszonális kapcsolatok kiépítését a szociálpszichológiai támogatáson keresztül. A sikeresen müködő rendszerben a munkavállalóban egyszerre alakul ki annak hite, hogy jó munkahelyi légkörben van, ahol a munkatársak támogatására, együttérzésére számíthat, és emellett a szakmai kihívás jelentőségét is átérzi, mert a munka tartalmához kapcsolódó kompetenciáinak fejlődését is célzottan segítette egy mentor. Mindez leginkább a magas veszteségek alapján értelmezett folytonos elkötelezettséget erösíti, amelyben kalkulatív, racionális alapon dönthet úgy a dolgozó, hogy számára nem éri meg egy esetleges munkahelyváltás, hiszen a jelenlegi munkahelyén mind a szakmai kiteljesedés lehetőségét, mind a teljes körü munkahelyi szocializáció lehetőségét megkapja.

\section{A hagyományos, formális, egyszemélyes mentoring hatása az erkölcsi meggyö- zödés alapú normatív elkötelezettségre}

Egy hazai nagyvállalat ügyfélszolgálati részlegén a mentorálás a HR írásbeli irányelveinek megfelelően müködik, a 18 munkavállaló közül két senior kolléga láthat el ilyen típusú feladatokat. A szervezetnél jelenleg átalakítás zajlik, a bizonytalanság miatt nagy a fluktuáció, folyamatosak a kilépések és a munkaerö-felvétel. Hagyományos, formális, egyszemélyi mentorálást alkalmaznak, melynek keretében a mentor folyamatos szakmai támogatást nyújt az új belépőnek. Az első hónapban a központi és az ügyfélszolgálatra vonatkozó belső szabályzatokat közösen tanulmányozzák át, majd a mentor munkavégzés közbeni megfigyelése következik körülbelül 2 hónapig. A mentor az ügyfelekkel való interakciók közben folyamatosan tájékoztatja az új belépőt arról, hogy az adott munkafolyamatra mely belső szabályzat milyen irányelve vonatkozik - így biztosítva, hogy az elméletben megbeszéltek elkezdjenek beépülni a gyakorlatba. A harmadik hónaptól kezdve három hónapon át az új belépő a háttérmunkálatok mellett heti két-három alkalommal ügyfeleket is behívhat, de ilyenkor a mentor figyelemmel kíséri a munkáját és visszakérdez a vonatkozó eljárásrendre. Az osztályvezető elmondása alapján az új kolléga két hónapig kizárólag tanul, semmilyen munkát nem tud végezni, a harmadik hónaptól már különböző adminisztratív, back office tevékenységekbe be tud segíteni, s fokozatosan, körülbelül az első év végére épül fel a munkaköri feladatok segítség nélküli ellátásához szükséges kompetenciakészlete. Volt rá példa, hogy egy-egy újonchoz két mentort tettek, egyikük inkább a munkavégzéshez kapcsolódó gyakorlatias ismeretekkel rendelkezett, a másik pedig precíz, pontos és szabálykövető volt. Többszörös mentorálást azonban csak abban az esetben alkalmaznak, ha az új belépőben látnak potenciált a későbbi magasabb szintủ, egyéb feladatok ellátására is. A szociálpszichológiai támogatásra sem az egyszemélyi, sem a többszörös mentorálás során nincs idő és energia, a szakmai ismeretek átadása ugyanis hosszadalmas és bonyolult folyamat. Mindehhez hozzátartozik, hogy az első időszakban a mentor kizárólag az új belépő betanításával foglalkozik, így munkaidejének nagy részét a mentorálás teszi ki.

A bemutatott gyakorlat elsősorban az erkölcsi meggyőződés alapú normatív elkötelezettséget erősíti. Az új kolléga nemcsak megkapott minden segítséget a betanulási folyamat során, de a tanultak döntő részét egyetlen mentor áldozatos munkájának köszönheti. A betanulás során a mentor elvégezte a feladatát, közben átadta a szükséges vállalati tudást is a mentoráltnak, mindez pedig úgy tartott hosszú hónapokon keresztül, hogy közben az integrációs folyamatban elég volt gyakran csak megfigyelnie. Kevés effektív munkát végzett, a munkabérét és egyéb járandóságait természetesen ezen időszakra ugyanúgy megkapta, de kézzelfogható eredményt a mentorálási folyamatból adódóan még nem produkált, miközben viszont tanúja volt annak, hogy a mentora megfeszített munkával végzi saját feladatait úgy, hogy lehetőleg ne csak átadja a tudását, hanem az esetleges buktatókra, a siker kritériumaira, az íratlan szabályokra is felhívta a figyelmét. Mindez hozzájárul ahhoz, hogy a dolgozó úgy érezze, vissza kell adnia a szervezet számára mindabból, amit az tett meg érte (természetesen nem céltalanul). Az erkölcsi alapú normatív elkötelezettség annál intenzívebb lesz, minél önzetlenebb volt a mentor e folyamatban, és minél tovább tartott az integrációs szakasz.

\section{A csoportalapú és egyenrangú mentoring hatása az affektív elkötelezettségre}

Egy multinacionális vállalat értékesítési munkakörében két éve múködik mentori rendszer, a bevezetését a magas fluktuáció indokolta. Általában hagyományos, formális, egyszemélyi mentori rendszer müködik, de bizonyos esetekben ez csoport-alapúvá és egyenrangúvá válhat. Egy mentor végzi minden új munkavállaló betanítását, így elfordulhat, hogy egyszerre két vagy három dolgozóval is foglalkoznia kell. Volt már olyan szituáció is, hogy az új munkatárs a vállalat egy másik 
munkaköréből került át az értékesítésre, így a folyamat során kölcsönösen tanultak egymástól. A területi vezető elmondása szerint ez azért nem volt szerencsés, mert a mentornak az első egy hónapban folyamatosan értékelnie az új munkavállalót, $\mathrm{s}$ az értékelés a kölcsönösségi viszony miatt nem volt kellően objektív.

Az értékesítés „területen” történik, ezért az új dolgozó az első héten minden nap elkíséri a mentort és megfigyeli munkavégzés közben, majd a második héten már önállóan dolgozik a mentor felügyeletével. Az új munkatárs teljesítményét a hét minden napján értékeli, az értékelés pedig egy célkitűzéssel zárul. A kitűzött célt már a következő napon meg kell valósítania az új belépőnek, ennek teljesülése is az értékelés részét képezi. A mentor a harmadik héttől kezdődően körülbelül fél évig maximum hetente egyszer, de legalább havonta kétszer kíséri el az újoncot, $\mathrm{s}$ a tevékenységét minden alkalommal minősíti. Az értékeléseket a területi vezetőnek is elküldi, aki az első 6 hónapban legalább havonta egyszer ugyancsak megfigyeli a munkavégzését. A mentor igyekszik nemcsak szakmai, hanem szociálpszichológiai támogatást is nyújtani, elmondása alapján így különösen nehéz meghúzni a határokat, volt már olyan tapasztalata is, hogy az új kolléga magánjellegủ problémákkal is megkereste. Az általános tapasztalat az, hogy legalább félév, de akár egy év is kell ahhoz, hogy az új értékesítőből teljes értékủ munkatárs váljon.

$\mathrm{Az}$ ebben az esettanulmányban bemutatott gyakorlat az érzelmi elkötelezettség fokozására kiváló példa. Az esetenként egyenrangúvá és csoportalapúvá váló mentori gyakorlat nemcsak a hatékonyabb beillesztést segíti elö, de a tekintélyelvü kultúra ellen is hat, amelyben a közvetlenség a szociális szükségletek kielégítésének adnak nagyobb teret. Bizonyos vezetői stílus alkalmazásában, ahol a feladat- és emberközpontúság egymásnak ellentmondó célokhoz kapcsolódnak, sikeres lehet ez a fajta mentoring gyakorlat a munkatársak affektív ragaszkodásának kialakítása és növelése során. A közvetlenség és egyenrangúság a mentort is esendőbb színben tüntetheti fel, míg a csoport-alapú müködés a személy mások általi gyors elfogadását, ezáltal az egyén intenzív pszichoszociális beilleszkedését segíti elö.

\section{ÖSSZEFOGLALÁS}

Tanulmányunkban a munkatársi elkötelezettség néhány dimenziójának egyes mentorálási gyakorlatokkal való összefüggéseit vizsgáltuk. Esettanulmányok segítségével illusztráltuk, hogy az elkötelezettség egyes változói célzottan fokozhatók konkrét, munkahelyi beillesztést segítő mentoring folyamattal. Eredményeink alapján a folytonos elkötelezettséget a többszörös mentorálás, a normatív elkötelezettség magas fokát a hagyományos, formális, egyszemélyes szakmai mentorálás támogatja. Az esetenként csoport-alapúvá és egyenrangúvá váló mentoring gyakorlat pedig leginkább az affektív elkötelezettséget segíti elő. Mindhárom esettanulmány legfontosabb tanulsága, hogy az új belépök szakmai és szervezeti integrációjának mentoringgal való segítése, valamint az ahhoz kapcsolódó aktív vezetői kapcsolattartás és odafigyelés nagyban hozzájárulhat a dolgozói elkötelezettség megalapozásához. Lényeges látni ugyanakkor azt is, hogy a szervezet kultúrája, tevékenységi köre és az ellátandó munkakör jellege nagymértékben befolyásolja, hogy milyen típusú mentoring folyamatot érdemes kialakítani. Célszerủ tehát nem keresni a „best practice”-eket, hanem e tényezőkhöz igazodva kimunkálni egy olyan - lehetöleg formalizált - gyakorlatot, amelynek segítségével megalapozható a dolgozói elkötelezettség egy vagy több dimenziója.

A tanulmányban bemutatott esetek érzékeltetik a mentoring gyakorlatok és az elkötelezettségi típusok kapcsolatrendszerét, de nem bizonyítják azokat, ehhez későbbi kvantitatív kutatások is szükségesek. További értelmezési korlát, hogy a bemutatott mentoring típusokat és az elkötelezettségi dimenziókat önkényesen választottuk ki, mert a teljes körü vizsgálat meghaladná e tanulmány kereteit. 


\section{HIVATKOZÁSOK}

Allen, T., Poteet, M., Russell, J., Dobbins, G. (1997), "A field study of factors related to supervisors' willingness to mentor others", Journal of Vocational Behavior, 50 1, 1-22 DOI: 10.1006/ jvbe.1995.1525

Allen, T., Eby, L., Poteet, M., Lentz, E., Lima, L. (2004), "Career benefits associated with mentoring for protéges: a meta-analysis", Journal of Applied Psychology, 89 1, 127-36 DOI: 10.1037/0021-9010.89.1.127

Angle, H. L., Perry, J. L. (1986), "Dual commitment and labor-management relationship climates", Academy of Management Journal, 29 1, 31-50 DOI: $10.5465 / 255858$

Baugh, G., Fagenson-Eland, E. A. (2007), "Formal Mentoring Programs: A „Poor Cousin” to informal relationship?" in: Ragins B., Kram $\mathrm{K}$. (eds.): The handbook of mentoring at work. SAGE, 249-72

Bene, Á. (2016), „Tehetség és oktatás a vállalatok társadalmi felelősségvállalásában”, Különleges Bánásmód, 2 2, 53-69

Bozionelos, N. (2004), "Mentoring provided: relation to mentors' career success, personality, and mentoring received", Journal of Vocational Behavior, 64 1, 24-46

Chao, G. (2007), "Mentoring and Organizational Socialization: Networks for Work Adjustment", in: Ragins B. Kram K. (eds.) The handbook of mentoring at work, SAGE, 179-96

Chao, G., Walz, P., Gardiner, P. (2006), "Formal and informal mentorships: a comparison on mentoring functions and contrast with nonmentored counterparts", Personnel Psychology, 45 3, 619-36 DOI: 10.1111/j.1744-6570.1992. tb00863.x

Clark, R., Harden, S., Johnson, B. (2000), "Mentor relationships in clinical psychology doctoral training: results of a national survey", Teaching of Psychology, 27 4, 262-68 DOI: 10.1207/ s15328023top2704 04

Cronan-Hillix, T., Davidson, W., Cronan-Hillix, W., Gensheimer, L. (1986), "Student's views of mentors in psychology graduate training", Teaching of Psychology, 13 3, 123-7 DOI: $10.1207 / \mathrm{s} 15328023$ top 13035

Csugány J. (2018), “A technológiai változások hatása a munkapiacra: Új kihívások és lehetőségek" Taylor Gazdálkodás- és Szervezéstudományi Folyóirat, 4 3, 26

Donaldson, S., Ensher, E., Grant-Vallone, E. (2000), "Longitudinal examination of mentoring relationships on organizational commitment and citizenship behavior", Journal of Career Development, 26 4, 233-49 DOI:
$10.1177 / 089484530002600401$

Ensher, E., Thomas, C., Murphy, S. (2001), “Comparison of traditional, step-ahead, and peer mentoring on proteges' support, satisfaction and perceptions of career success: a social exchange perspective", Journal of Business and Psychology, 15 3, 419-38

Erdélyi E. (2018), "Hitt kerék 7. pont: felkészítés (képzés és fejlesztés)", in: Gulyás L. (szerk.): $A$ vezetéstudomány alapjai. Szeged: Jatepress, 187-99

Gergely É. (2016), “Karriervizsgálatok egyetemisták körében”, Közép-Európai Közlemények, 9 2, 134-45

Grossman, S. (2013), Mentoring in Nursing. A Dynamic and Collaborative Process, Springer

Hoffmeister, K. (2011), "A perspective on effective mentoring in the construction industry", Leadership \& Organization Development Journal, 32 7, 673-88 DOI: 10.1108/01437731111169997

Juhász I. (2019), „Pályaalkalmassági vizsgálatok és alkalmazásuk az emberi erőforrások kiválasztásában - különös tekintettel a személyiségtesztekre", Munkaügyi Szemle, 62 5, 65-74

Kelló É. (2018), “Coaching alapok”, in: Kelló É. (szerk.), Coaching alapjai és irányzatai, 23-72, Budapest: Akadémiai Kiadó

Kohn, S., O’Connell, V. (2015), 9 Powerful Practices of Really Great Mentors: How to Inspire and Motivate Anyone, Weiser

Kozák A., Krajcsák Z. (2018), "Retaining the Rookie - Role Clarification through Mentorship", Human Systems Management, 37 1, 95-103 DOI: $10.3233 / \mathrm{hsm}-17108$

Levinson, D. (1978), The Seasons of Man's Life, USA: Ballantine Books

Meyer, J. P., Allen, N. J. (1991), “A three-component conceptualization of organizational commitment", Human Resource Management Review, 1 1, 61-89 DOI: 10.1016/10534822(91)90011-z

Meyer, J. P., Parfyonova, N. M. (2010), "Normative commitment in the workplace: A theoretical analysis and re-conceptualization", Human Resource Management Review, 20 4, 283-94 DOI: 10.1016/j.hrmr.2009.09.001

Miller, A. (2002), Mentoring students and young people, Sterling, VA: Stylus Publishing

Niehoff, B. (2006), "Personality predictors of participation as a mentor", Career Development International, 11 4, 321-33 DOI: $10.1108 / 13620430610672531$

Okurame, D. (2012), "Linking work-family conflict to career commitment: the moderating effects of gender and mentoring among Nigerian civil servants", Journal of Career Development, 39 5, 423-42 DOI: 10.1177/0894845310391903 
Ragins, B., Cotton, J. (1993), "Gender and willingness to mentor in organizations", Journal of Management, 19 1, 97-111 DOI: $10.1177 / 014920639301900107$

Szondi R. - Gergely É. (2018), “A teljesítményértékelés és a mentorálás szerepe a gyako- rnoki programban", Taylor: gazdálkodás- és szervezéstudományi folyóirat, 10 1, 139-48

Wilson, J., Elman, N. (1990), "Organizational benefits of mentoring", Academy of Management Executive, 4 4, 88-94 DOI: 10.5465/ ame.1990.4277215

Kozák Anita PhD, föiskolai docens kozak.anita@uni-eszterhazy.hu Eszterházy Károly Egyetem

Krajcsák Zoltán $\mathrm{PhD}$, egyetemi docens krajcsak.zoltan@uni-bgf.hu Budapesti Gazdasági Egyetem

\section{The correlation between the mentoring practices helping the onboarding process and the workers' commitment}

\section{THE AIMS OF THE PAPER}

This paper is to outline what kind of correlations may be revealed between the dimensions of the workers' commitment and the mentoring practices used during the onboarding process. The article presents the relationships system between the various mentoring solutions (multiple, traditional, one-person, in some cases group based ---or equal ones) and the continuous, normative and affective aspects of commitment.

\section{METHODOLOGY}

The authors present mentoring practices with the help of some case studies. It is important to note here that the actual cases presented merely model the correlation between the mentoring practices and the dimensions of commitment. To prove the validity of this correlation, further, quantitative studies need to be carried out.

\section{MOST IMPORTANT RESULTS}

According to our results, the continuous commitment is supported by multiple mentoring (as interpreted on the basis of the high rate of losses). In this case, the organizational integration helps the workers' professional development and their identification with the company culture. The normative commitment, which is based on one's moral conviction, is helped by the traditional, formal and one-person mentoring. In this case, the learning process is slower but more professional. On the other hand, the leaders' care can be seen in the well-considered and multi-phased delivery of the knowledge and practices. This process takes time and can strengthen one's feeling of being obliged to the organization and the desire for moral renumeration. The mentoring practice which sometimes becomes group-based and equal helps most to achieve a high level of affective commitment. In this kind of practice, the support of socio-psychology overwrites the professional aspects

\section{RECOMMENDATIONS}

In the present environment of labour shortage, increasing the workers' commitment is especially important for the HR and the management. Due to the high rate of fluctuation, it is very important to found the workers' commitment in the initial period of their employment. The studies processed point out that some commitment variables can be improved with specific mentoring practices.

Keywords: retention management, continuous commitment, affective commitment, normative commitment, mentoring 